\title{
Legal regulation of Islamic leasing in the Republic of Uzbekistan
}

\section{Shavkat BOZAROV ${ }^{1}$}

Lawyer of Leasing association of Uzbekistan

\section{ARTICLE INFO}

\section{Article history:}

Received September 2020

Received in revised form 15

September 2020

Accepted 25 September

2020

Available online

1 October 2020

\section{Keywords:}

Islam

Ijara

Riba

Haram

Garar

Maisir

\section{ABSTRACT}

Considered the correlation between the legal regulation of conventional leasing relations in the Republic of Uzbekistan and the legal regulation of one of the most dynamically developing Islamic products in the world - Islamic leasing, Ijara.

Evaluated the possibilities of applying the current legislation of the Republic of Uzbekistan regulating conventional leasing relations to Islamic leasing - Ijara. Considered the application of the most important provisions of the current leasing legislation of the Republic of Uzbekistan in relation to the regulation of Ijara

Proved the possibility of implementing Islamic leasing - Ijara on the basis of the current leasing legislation of the Republic of Uzbekistan and presented proposals for a wider implementation of this type of financial services

2181-1415/C 2020 in Science LLC.

This is an open access article under the Attribution 4.0 International (CC BY 4.0) license (https://creativecommons.org/licenses/by/4.0/deed.ru)

\section{Ўзбекистон Республикасида ислом лизингини хуқуқий тартибга солиш}

Калит сузлар:
Ислом
Ижара
Рибо
Харом
Гарар
Майсир

\section{Калит суцзлар:}

Рибо

Майсир

\begin{abstract}
АННОТАЦИЯ
Кўриб чиқилган масала Ўзбекистон Республикасида анъанавий лизинг муносабатларини хуқуқий тартибга солиш билан биргаликда жахон миқёсида ривожланиб келаётган ислом молия хизмаларидан бири бўлмиш ижарани хуқуқий тартибга солиниши таққосланишига бағишланди.

Ўрганилиш жараёнида Ўзбекистон Республикасида анъанавий лизингни тартибга соладиган миллий қонунчилик тахлил қилиниб, унинг меъёрларини ислом лизинги - ижарага қўлланиш имкониятларига хуқуқий бахо берилди. Ўзбекистон Республикасида амалдаги
\end{abstract}

\footnotetext{
${ }^{1}$ Lawyer of Leasing association of Uzbekistan, independent research applicant Tashkent, Uzbekistan email: shavkatbozarov2@gmail.com
} 


лизинг қонунчилигига кирадиган асосий меъёрий
хужжатларнинг мухим қоидалари ижарага нисбатан
қўлланиши кўриб чиқилди.
Тахлиллар натижасида ислом лизинги бўлмишижарани
Ўзбекистон Республикасининг лизинг қонунчилиги
асосида амалга ошириш мумкинлиги исботланди ва
молиявий хизматнинг ушбу турини тадбиқ этишни
кенгайтириш бўйича таклифлар келтирилди

\section{Правовое регулирование исламского лизинга в Республике Узбекистан}

\section{Ключевые слова:}

Миф ислам

Иджара

Риба

Харам

Гарар

Майсир

\begin{abstract}
АННОТАЦИЯ
Рассмотрено соотношение правового регулирования традиционных лизинговых отношений в Республике Узбекистан с правовым регулированием одного из динамично развивающегося во всем мире исламских продуктов - исламским лизингом, ижарой.

Оценены возможности применения действующего законодательства Республики Узбекистан, регулирующего традиционные лизинговые отношения, к исламскому лизингу - ижаре. Рассмотрено применение важнейших положений действующего лизингового законодательства Республики Узбекистан применительно регулирования ижары.

Доказана возможность осуществления исламского лизинга - ижары на основании действующего лизингового законодательства Республики Узбекистан и изложены предложения для более широкого внедрения данного вида финансовқх услуг
\end{abstract}

\section{SUMMARY}

All over the world, Islamic Finance is showing dynamic growth. In order to introduce Islamic Finance in the Republic of Uzbekistan, a Working group has been established under the President office, which develops proposals for making a legal framework for the introduction of Islamic Finance and creating the appropriate infrastructure. The purpose of this article is to substantiate the possibility of introducing one of the types of Islamic financial services - Ijara on the basis of the current legislation of the Republic of Uzbekistan. To substantiate this position, the author analyzes the current leasing legislation of the Republic of Uzbekistan and indicates the possibility of compliance with the principles of Islamic Finance in the provision of Izhar services by making certain conditions in the concluded contracts of Islamic leasing of Izhar. For example, compulsory insurance of a leasing object allows you to resolve the issue of releasing the lessee from obligations to the lessor under the lease agreement in case of accidental loss or damage to the leasing object.To eliminate the interest income provided for in article 22 of the law of the Republic of Uzbekistan "On leasing", but prohibited by the principles of Islamic Finance, the author suggests that the lease agreement should 
provide for the dependence of the lessor's income on the results of the lessee's activities and the distribution of the lessor's losses in case of its failure. Moreover, research shows that the provisions of the leasing legislation of the Republic of Uzbekistan regarding the establishment of essential terms of the leasing agreement allow to eliminate uncertainty - garar, which is a very important factor for recognizing the Islamic leasing agreementIjara as valid. Despite the possibility of providing Ijara services on the basis of the current leasing legislation of the Republic of Uzbekistan, the author of the scientific article proposes to adopt a special law on Islamic finance, which will also contain rules related to the regulation of the features of Islamic leasing - Ijara.

Currently, the Republic of Uzbekistan is working on the introduction of Islamic finance. The Working group established under the President office includes the heads of some financial authorities - the Central Bank, the Ministry of Finance etc. As representative of commercial sector of the financial system, this Working group includes the Chairman of the National Bank for foreign economic Affairs of the Republic of Uzbekistan, which is the country's leading commercial bank and has more than $40 \%$ of all second level banks assets. The Working group is studying the possibilities of introducing Islamic financial products in Uzbekistan, the state of the current banking sector of the Republic in terms of launching Islamic banking, the needs of society and economy for alternative financial products based on the principles of Islam.

It is generally agreed that the introduction of Islamic finance requires the adoption of relevant legislarive acts in the form of a separate law or amendments and additions to a number of existing laws (the Civil code of Uzbekistan, the laws of Uzbekistan "On banks and banking activities", "On the securities market", "On insurance activity", etc.), numerous instructions of the Central Bank and the Ministry of Finance in the field of prudential supervision, in the field of insurance regulation, etc. It should be noted that in the process of preparing the draft of the new Civil code of Uzbekistan, implemented in accordance with the Order of the President №5494 dated April 5, 2019 some work has been done in the field of creating legal bases for the introduction of Islamic leasing, including the draft of the new Civil code excludes norms that are a barrier to the introduction of Islamic finance.

Ijara as an Islamic financial product is in high demand in countries where the necessary legal framework and market infrastructure have been created for Islamic finance. Of course, Islamic Ijara is not similar to conventional leasing, or at least to rent in the sense set out in the Civil code of Uzbekistan, but it can be safely stated that the goals and objectives of participants in Ijara and leasing coincide and that the mechanism for implementing Ijara and leasing have not much differences.

Conventional leasing in Uzbekistan is regulated by Chapter 34 of Civil code, paragraph 6 of which is devoted to the leasing agreement, by law "On leasing" dated April 14,1999 , and certain provisions of the Tax code. In Uzbekistan leasing activities are not licensed, and leasing activities are regulated by authorities on a general basis, mainly for taxing proposes. To create a leasing company, it is enough to register a legal entity whose Charter provides for the provision of leasing services. Leasing operations can legally be performed by any legal entity whose Charter does not prohibit the provision of leasing services. Supervision of leasing activities within the framework of general state 
supervision of economic activities is carried out mainly in the form of offsite supervision by the tax authorities, and, mainly, the correct calculation and payment of VAT [8, p.81].

Conventional leasing is carried out under a three-side scheme, when a leasing company or bank, on behalf of an economic entity, purchases equipment and transfers it to this economic entity for temporary possession and use, and the economic entity pays it a pre-agreed amount of leasing payments. Leasing is beneficial to all three parties to the transaction: the lessee gets the necessary equipment without additional financial expenses for its purchase; the leasing company earns additional income through lease payments, the total amount of which includes the cost of purchasing equipment and its income; the equipment seller sells its products, receiving its full price.

Islamic leasing - Ijara can also be carried out under the same scheme. However, in order to provide the Ijara, the following principles of Islamic finance must be observed:

1) prohibition on the lessor receiving a pre-determined income, the lessee's acceptance of the obligation to provide for which is a necessary condition for receiving the leasing service. In Islam, such income is called "Riba" and it is forbidden in the Koran. Instead of a fixed income during the implementation of Ijara, the lessor can claim a part of the income that the lessee will receive as a result of using the leased equipment object [11, p.37]. However, in the event of negative results in the activities of the lessee, the lessor risks not only being left without the profit that he expected, but also to suffer losses associated with the loss or deterioration of the lease object. This principle of operation in international practice is called Profit and loss share, when the parties to a transaction agree to share both profit and loss from cooperation.

2) prohibition of the purchase and transfer to Ijara of equipment that can be used for the production of goods, works and services prohibited by Islam. It's banned to finance in the form of Ijara, for example, the purchase and leasing of equipment for the production of alcohol and tobacco products, pork processing, etc. The term "Haram" in the sphere of Islamic Finance, as in Islam in general, means objects and actions that are strictly and unequivocally prohibited for Muslims. Anything related to Haram should not be directly or indirectly involved in an Islamic finance, including the process of providing an Ijara service.

3) prohibition of uncertainty when providing an Ijara transaction. The term "Gharar" is translated from the Arabic verb "gharara/gharra", which means "to expose yourself and your property to ruin without realizing it." Company or individual can not conclude transactions without determining its subject or in the absence of goods [9, p.15]. In the Islamic law of Fiqh, this concept is regulated in detail, many lawyers of Islam have devoted their papers to this issue, but even now there are situations when experts do not have a common opinion about the presence of an indefinite agreement, which may lead to its invalidity. In one of the hadiths, it is said that the prophet Muhammad was against the sale of fish not yet caught in the sea, because it is not known what kind of fish swims there, what is the fishing opportunities, etc.

4) prohibition on financing activities related to gambling, i.e. the possibility of obtaining a certain income associated with a random combination of circumstances. For such cases the term "Maisir" is used, when the subject of public relations receives undeserved income without producing any goods or performing any useful activities. 
Simply put, a leasing company that provides services to Ijara does not have the right to lease equipment to casinos, gambling houses, equipment for conducting lotteries, etc.

Although there is currently no legal framework in Uzbekistan for the large-scale introduction of Islamic Finance, according to the author of this article, the current legislation of Uzbekistan allows leasing companies to provide Ijara services, although other products of Islamic Finance require the creation of a special legal framework. Compliance with the above-mentioned prohibitions is possible if the shareholders and investors of leasing companies wish and they have "clean", free from riba, haram and maisir (i.e. not attracted at interest, not earned from prohibited activities and gambling) sources of financing, which is quite possible in Uzbekistan. The question of the prohibition of gharar in Ijara is not relevant, as will be discussed later.

In order to comply with the principles of Islamic Finance, the management of the leasing company must make a firm decision on the launch of the Islamic product Ijara complying with the above prohibitions. The leasing company should cooperate with the lessee and consider it as a partner, and be always ready to share both profit and loss with the lessee. In its policy, the leasing company should clearly define a ban on financing activities that are at least to some extent replaced in the production of goods, works and services classified as haram and maisir.

According to the author, in the light of the existing legal norms governing the lease agreement, garar deserves special consideration in the process of providing Ijara. The fact is that the civil legislation of Uzbekistan, which is based on Romano-German law, sets certain requirements for the conditions for concluding certain types of contracts. Following the tradition of the Romano-Germanic system of law, the Uzbek legislator sets for many types of contracts a list of essential conditions that must be agreed upon by the parties for their entry into legal force. In particular, part three of article 9 of the Law of the Republic of Uzbekistan "On leasing" establishes the following essential terms of the lease agreement:

description of the leased object, including quantitative and qualitative characteristics, the contract value of the leased object, other parameters, as well as the total amount of the contract;

obligations assumed by the parties in connection with the acquisition and delivery of the leased object;

procedure for transfer of the leased object, including the procedure for delivery, installation and putting into operation of the leased object;

basic conditions for making lease payments;

obligations of the parties to the agreement related to the use, storage, maintenance and repair of the leased object;

term of the lease agreement;

indication of the party to the agreement responsible for selecting the seller and the leasing object $[2$, p.7].

In accordance with the first part of article 364 of the Civil code, only when these conditions of the leasing agreement providing Ijara services are agreed upon, legally binding rights and obligations arise between the parties [1, p.137].

Even a cursory glance at the essential terms of the lease agreement, without their deep and comprehensive analysis, shows that in order to conclude a leasing agreement, 
the parties must conduct such preliminary work that, in principle, eliminates uncertainty. To enter into a leasing agreement that meets the requirements of Ijara, the lessee must specify exactly the object of leasing, its quantitative and qualitative parameters, its supplier, the parties must agree on its price, terms and delivery procedure, agree and sign the schedule of leasing payments with a detailed indication of the frequency, size, currency, and payment procedure. Therefore, as a rule, the question of garar does not arise when providing Islamic leasing Ijara.

The existence of the above prohibitions has a certain impact on the rights, duties and responsibilities of participants in Ijara [7, p.9-10 ]. In particular, in contrast to conventional leasing, where the key point is the transfer to the lessee of the risk of loss and damage, despite the retention of ownership by the lessor, in the case of Ijara, these risks are retained by the lessor. In practice, this means that in the event of theft, accident, accidental damage, etc. of the leased object, the lessee is released from its obligations to the lessor. In conventional leasing, the lessee is obliged to compensate the lessor for its losses in such cases. In order to avoid this, the leasing legislation provides for mandatory insurance of the leased object and coverage of damage to the lessor by the insurance company. However, if the insurance policy has not been issued or extended properly, the lessee is obliged to compensate the lessor for its losses.

In order to avoid this contradiction in Ijara agreement, the parties may provide for the release of the lessee from liability for obligations under the agreement in the event of accidental loss or damage to the leased object. Such terms of Ijara agreement will not contradict the requirements of the leasing legislation of Uzbekistan.

There are also differences in the process of making payments in conventional leasing and Ijara. In the case of conventional leasing, the lessee pays interim leasing payments from the moment of conclusion of the leasing agreement until receipt of the leased object, as well as during the period when the lessee was unable to use the leased object for reasons beyond the control of the lessor. In the case of Ijara, the lessee pays leasing payments only for the time when it had a real opportunity to use the leased object, i.e. it is exempt from interim lease payments and payments for the period when it was not able to use the leased object for any reason. The inclusion of such rules in Ijara agreement will not contradict the legislation of Uzbekistan

Article 22 of the law "On leasing" stipulates that leasing payments include the lessor's expenses for the acquisition of the leased object and the lessor's interest income. The lessor's interest income is, in the general opinion of experts in this field, a category covered by the concept of "haram" and therefore unacceptable for Ijara. However, according to the author of this article, the parties to the Ijara agreement may provide that the lessor's income will be determined based on the results of the lessee's activities. Even including conditions on the percentage of the lessor's future income (for example, in order to strictly comply with the requirements of the above-mentioned article of the law "On leasing"), the parties may make a reservation that in the event of unfavorable results of the lessee's activities in using the leased object, the parties will distribute the losses from the leasing transaction among themselves.

Despite the fact that the current civil legislation of Uzbekistan allows for leasing transactions in compliance with the principles of Islamic Finance, according to the author, it is necessary to adopt a law regulating the main issues of providing financial 
services in accordance with the principles of Islamic Finance, including Ijara. The adoption of a special law, where along with other Islamic products such as Mudoraba, Murobakha, Musharaka, etc., issues related to Ijara will also be resolved. A special law will regulate such key issues related to Ijara as obtaining an expert opinion on the compliance of the proposed Ijara with the principles of Islamic Finance, separate accounting in financial institutions that offer both Ijara and conventional leasing in parallel, peculiarities of taxation of penalties collected for violation of the lessee's obligations, and others.

\section{References:}

1. Civil code of Uzbekistan. - Tashkent: Adolat, 2017.

2. Law of Uzbekistan «On leasing» // Vedomosti of Oliy Majlis of the Republic of Uzbekistan, 1999 г., № 5, art. 108.

3. Law of Uzbekistan «On banks and banking activity» // National database of legislation, 06.11.2019 г., № 03/19/580/3994; 07.01.2020 г., № 03/20/600/0023.

4. Law of Uzbekistan «On insurance activity» // Vedomosti of Oliy Majlis of the Republic of Uzbekistan, 1999 г., № 5, art. 108..

5. Tax code of Uzbekistan. - Tashkent: Adolat, 2020.

6. Abbas Mirakhor Zamir Iqbal. An Introduction to Islamic Finance: Theory and Practice, Edition 2 / Zamir Iqbal Abbas Mirakhor, 2011. - P. 1

7. Mufti Muhammad Taqi. An Introduction to Islamic Finance 2002. - P. 9-10.

8. Muhammad Ayub. Understanding Islamic Finance. 2009. - P. 81-82

9. Mahmoud A. El-Gamal. An Economic Explication of the Prohibition of Gharar in Classical Islamic Jurisprudence. 2001.

10. Samir Abid Shaikh. The anatomy of Usury: A Critique of the Interest Based Economic System. - Charleston, SC, USA. - 2013.

11. Wayne A.M. Visser and Alastair McIntosh. A Short Review of the Historical Critique of Usury (Riba) // https://www.lariba.com/knowledge-center/ribahistory.htm

12. Беккин Р.И. Исламская экономическая модель и современность. 2016, 2-е изд. М.: ИД Марджани, с.8

13. Е.А. Байдаулет. Основы этических (исламских) финансов. ISBN 978-6017205-96-6. УДК 339.7(075.8) ББК 65.268я73

14. С. Харон, Ван Нурсофиза Ван Азми. Исламская финансовая и банковская система: философия, принципы и практика / Судин Харон, Ван Нурсофиза Ван Азми. - Казань : Линова- Медиа, 2012. - 536 с.

15. С.Харон, З.А.Азиз. Исламские финансы и банковская система: философия, принципы и практика/ С.Харон, 3.А.Азиз - Казань. Татарстан - 2012. 